\title{
Glucagonoma syndrome associated with necrolytic migratory erythema
}

\author{
SíndROME dO GLUCAGONOMA ASSOCIADO A ERITEMA NECROLÍTICO MIGRATÓRIO \\ Florentino de Araújo Cardoso Filho ${ }^{*}$, Roney Gonçalves Fechine Feitosa ${ }^{2}$, Carolina Oliveira Costa Fechine ${ }^{3}$, \\ Carlos Márcio Melo de Matos ${ }^{4}$, Amanda linhares Cardoso ${ }^{5}$, Daniel linhares Cardoso 6 \\ ${ }^{1}$ MSc in Surgery from the Universidade Federal do Ceará (UFC). MD, MSc, TCBC, FACS, President of the Associação Médica Brasileira, Fortaleza, CE, Brazil \\ 2Resident in Plastic Surgery, Last year training as Resident in Plastic Surgery at Universidade Federal de São Paulo (Unifesp), São Paulo, SP, Brazil \\ ${ }^{3}$ Dermatologist with a degree from the Hospital do Servidor Público do Estado de São Paulo, São Paulo, SP, Brazil \\ ${ }^{4}$ Resident in General Surgery at the Dr. César Cals de Oliveira Hospital, Fortaleza, CE, Brazil \\ ${ }^{5}$ Medical Student, $7^{\text {th }}$ period, at Universidade Christus, Fortaleza, CE, Brazil \\ ${ }^{6}$ Medical Student, $20^{\text {th }}$ period, Universidade de Fortaleza, Fortaleza, CE, Brazil
}

Study conducted at the Department of General Surgery, Hospital Geral de Fortaleza, Fortaleza, CE, Brazil

Article received: $4 / 1 / 2015$ Accepted for publication: 4/27/2015

*Correspondence: Address: Av. Dom Luis, 1233 - S/407 Aldeota

Fortaleza, CE - Braz Postal code: 60160-230 roneyfechine@gmail.com

http://dx.doi.org/10.1590/1806-9282.61.03.203

Conflict of interest: none

\section{SUMmaRY}

Introduction: glucagonoma is a pancreatic neuroendocrine tumor derived from alpha-cells of the islets of Langerhans. It is marked by tumoral autonomous production of glucagon and characterized, among other symptoms, by necrolytic migratory erythema, an erythematous circinate lesion with areas of necrosis and sloughing. This is a rare disease with worldwide incidence estimated at 1 case per 20 million people.

Case report: we report a case of glucagonoma associated necrolytic migratory erythema in a male patient, 56 years, with signs of skin lesions mainly on his legs and groin, hyperglycemia and weight loss. Biopsies of the skin lesions were performed and imaging of the abdomen showed a mass of $10 \times 9 \mathrm{~cm}$, at the pancreatic region. The patient was subjected to body-caudal pancreatectomy and splenectomy with autotransplant of the spleen in the greater omentum. The histopathologic report indicated a tumor in the pancreatic alpha cells. Immunohistochemistry showed expression of glucagon and chromogranin A in most tumor cells, consistent with the diagnosis of glucagonoma. The patient presented 3 years of outpatient follow-up with no complications.

Conclusion: the necrolytic migratory erythema is important for the clinical recognition of glucagonoma, and its early diagnosis is essential for a successful curative therapy.

Keywords: necrolytic migratory erythema, glucagonoma, pancreatic neoplasms, neuroendocrine tumors.

\section{INTRODUCTION}

Glucagonoma is a pancreatic neuroendocrine tumor derived from alpha-cells of the islets of Langerhans. It is usually discovered through identification of a glucagonoma syndrome, which includes tumoral autonomous production of glucagon, and is characterized by necrolytic migratory erythema (NME), diabetes mellitus, weight loss, deep vein thrombosis, neuropsychiatric disorders and diarrhea. ${ }^{1,2}$

NME is the hallmark of this syndrome, characterized by circinate erythema with areas of necrosis and slou- ghing. It can be the first manifestation of the disease and its recognition may suggest the diagnosis. ${ }^{3}$

It is a rare disease that, combined with glucagonoma syndrome, has an estimated global incidence of 1 case per 20 million people. ${ }^{2}$

We present a glucagonoma syndrome case report associated with NME, described in a patient treated in a public hospital in the state of Ceará with distal pancreatectomy and total splenectomy, resulting in complete resolution of skin lesions. 


\section{Case report}

A 56-year-old male patient was referred to the general surgery service of a hospital in Ceará to perform skin biopsy. He had diffuse and recurrent erythematous, erosive lesions, mainly in lower trunk, inguinal region (Figure 1) and lower limbs for nine years without remission with medical treatment. Patient had little glycemic control with oral hypoglycemic agents and diet. He denied alcohol consumption or smoking habit. On examination, the patient was in good general condition, thin, with reddish-crusted lesions, mainly in lower trunk, inguinal region and lower limbs; erosive and blistering lesions in the perioral area. Abdomen without visceromegaly or palpable masses. Laboratory tests: presence of mild normocytic and normochromic anemia, abnormal glucose tolerance test, reduced albumin and total protein levels, and amino acids quite diminished.

Skin biopsy was performed, with histopathology compatible with epidermal necrosis observed in the upper third of the epidermis with superficial peeling and cracking in the stratum corneum, hyperkeratosis with neutrophils in the superficial layers.

In the investigation, abdominal ultrasound (US) was requested, evidencing a mass in the epigastric area on pancreatic topography of approximately $9.0 \times 6.0 \mathrm{~cm}$. Computed tomography (CT) of the abdomen was performed to characterize more precisely the pancreatic tumor; thus, a hyperdense mass was confirmed on body-tail pancreatic topography of approximately $10 \times 9.0 \mathrm{~cm}$ with mild degree of contrast enhancement (Figure 2). Upper GI endoscopy (EGD) showed diffuse gastritis and slight bulging of the posterior gastric wall, suggesting extrinsic compression.

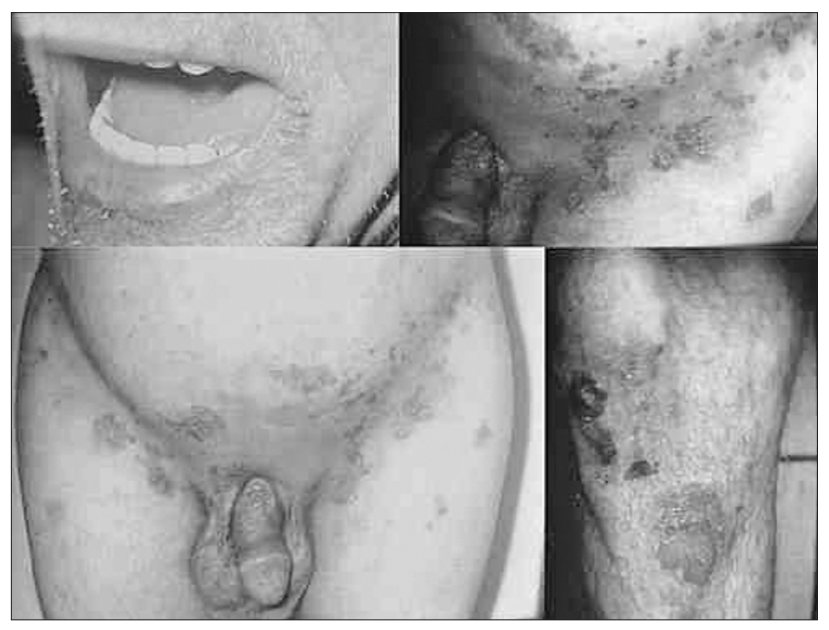

FIGURE 1 Erythematous, crusted plaques in perioral, inguinal and genital areas, and lower limbs.

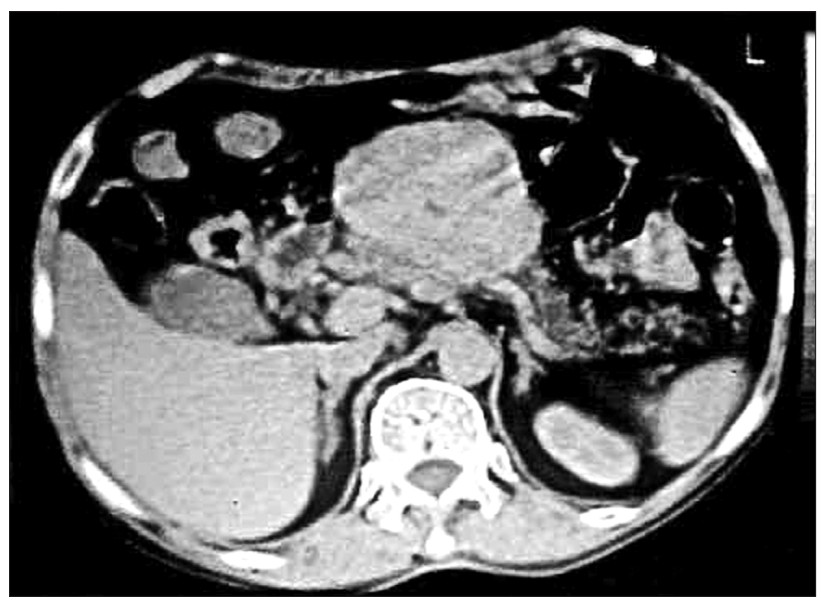

FIGURE 2 Computed tomography $(C T)$ of the abdomen showing a hyperdense mass on body-tail pancreatic topography measuring approximately $10 \times 9 \mathrm{~cm}$ with mild degree of contrast enhancement. There was no evidence of metastases.

Preoperative enteral and parenteral nutrition were introduced. Body-caudal pancreatectomy (approximately 80\% of the pancreas) and total splenectomy (Figure 3) were performed with spleen autotransplantation in greater omentum, due to tumor sized $10 \times 8.0 \mathrm{~cm}$, encapsulated and with fibroelastic consistency. The histopathologic report indicated a tumor in the pancreatic alpha cells. Immunohistochemistry showed expression of glucagon and chromogranin A in most tumor cells (consistent with the diagnosis of glucagonoma).

In the postoperative period, the patient progressed with surgical wound infection, left subphrenic abscess and distal pancreatic fistula. Complications were resolved 30 days after surgery, using surgical approach and nutritional supplementation. Improvement of glucose tolerance curve and normalization of serum levels of glucagon (postoperative glucagon $66 \mathrm{pg} / \mathrm{mL}$ ) were observed, as well as evidence of splenic metabolism in the scintigraphy with $400 \mathrm{MBq}$ of Tc-99m-colloid.

Patient received outpatient follow-up for 3 years, without clinical complications.

\section{Discussion}

Becker et al., ${ }^{4}$ in 1942, were the first to describe the association of a rash, later called necrolytic migratory erythema (NME) by Wilkinson ${ }^{5}$ in 1973 , to pancreatic cancer. But it was only in 1966 that McGavran et al. ${ }^{6}$ organized these conditions as a glucagonoma syndrome.

It is a very rare disease. A study carried out in the US showed the occurrence of only 2,705 cases of pancreatic 


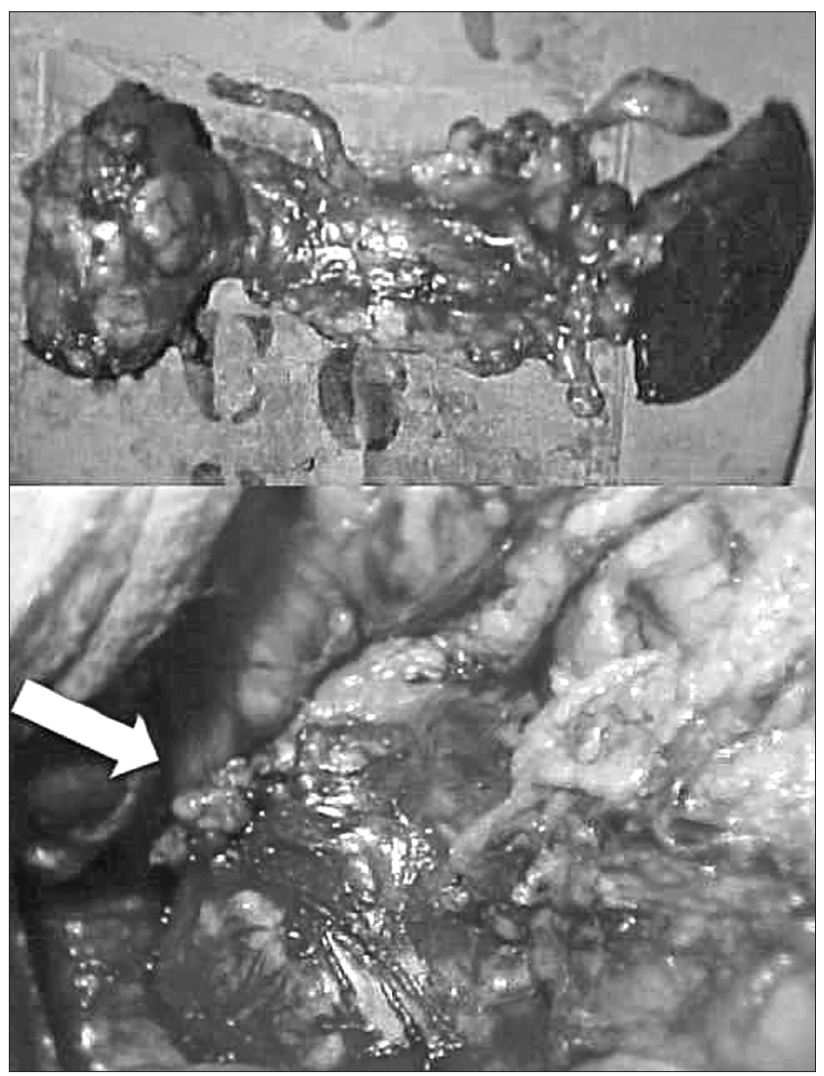

FIGURE 3 Product of body-caudal pancreatectomy (approximately $80 \%$ of the pancreas) and total splenectomy with tumor evident to the left of the image.

neuroendocrine tumors in a period of 28 years, with glucagonomas in only $1.3 \%$ of these neoplasms. ${ }^{7}$

NME is present in almost $70 \%$ of patients with glucagonoma. ${ }^{8}$ The lesions consist of erythematous crusted plaques, seen most often in the groin, intergluteal and genital area. It is also found in the lower limbs, perioral region, trunk or even in a pattern of widespread distribution. It is characterized by spontaneous exacerbation and remission periods without the identification of a trigger. ${ }^{9}$

Histologically, NME can be characterized by paleness and spongiosis of the upper layer of the epidermis. A perivascular lymphocytic and histiocytic infiltrate is also frequent. Necrotic keratinocytes are common and can lead to erosions, crusting and scaling. ${ }^{10}$

Pathogenesis has not been fully clarified, but is attributed to zinc deficiency and hypoaminoacidemia. ${ }^{11}$ It is believed that an increase in glucagon levels can lead to loss of amino acids, secondary to increased gluconeogenesis. ${ }^{12}$ In the reported case, hypoaminoacidemia and raised glucagon levels were present before resection. After the surgery, there was a significant decrease in the levels of glucagon (postoperative glucagon $66 \mathrm{pg} / \mathrm{mL}$ ), confirming the diagnosis of glucagonoma and the association between hyperglucagonemia and hypoaminoacidemia.

Clinically, glucagonoma can manifest with symptoms such as: weight loss, diabetes, diarrhea, and stomatitis. However, patients often seek medical attention for the first time due to skin changes, ${ }^{13}$ many times attributed to eczema or psoriasis. Due to the difficulty of recognizing the NME and its association with glucagonoma syndrome, patients remain without a correct diagnosis for a long time. ${ }^{14}$ In the present case, there was a delay diagnosis attributable to loss of clinical follow-up of the patient and the difficulty in recognizing the skin lesion - which at first was the only complaint of the patient.

Additional investigation can be made by angiography, computed tomography (CT) or magnetic resonance imaging (MRI). These last two enable a better study of the pancreas, helping to characterize the tumor site accurately, which in $86-88 \%$ of cases is in the tail of the pancreas. ${ }^{15}$ Selective visceral angiography is considered the gold standard for diagnosis and localization of these tumors, and its superiority is related to the hypervascularization of these tumors, ${ }^{16}$ despite our case report showing a lesion with mild degree of contrast enhancement. Another advantage of this method is the possibility to demonstrate liver metastasis even in cases where these implants are not seen with CT. ${ }^{16}$ Positron Emission tomography (PET) and octreotide scintigraphy have a prominent role, as almost all studied glucagonomas have receptors for somatostatin. ${ }^{17}$ However, methods such as abdominal US or CT with contrast is often sufficient to diagnose because the tumors are often characterized by single and large tumor masses (ranging from 1 to $30 \mathrm{~cm}^{3}$ ).

Currently, the only curative therapy is surgical removal of the mass, which can be done either by open surgery (conventional) or laparoscopically. For those with metastatic liver disease, there are studies showing that these patients may benefit from therapies that reduce the hepatic arterial circulation of metastases by hepatic artery embolization, either using chemoembolization or microsphere radioembolization. ${ }^{18}$ Other possible treatments for disseminated disease in the liver would be liver transplantation, ${ }^{19}$ cryoablation or metastasectomy. ${ }^{16}$ For patients with contraindications to surgery, chemotherapy with doxorubicin and streptozotocin can be performed, leading to a more selective damage of pancreatic islet cells. ${ }^{20}$ 


\section{Conclusion}

NME is crucial for the clinical recognition of glucagono$\mathrm{ma}$, and early diagnosis is very important for a curative therapy.

\section{Resumo}

Síndrome do glucagonoma associado a eritema necrolítico migratório.

Introdução: o glucagonoma é um tumor neuroendócrino do pâncreas derivado das células alfa das ilhotas de Langerhans. É marcado pela produção tumoral autônoma de glucagon e caracterizado, dentre outros sintomas, por eritema necrolítico migratório (ENM), uma lesão eritematosa circinada com áreas de necrose e descamação. Trata-se de uma doença rara com incidência mundial estimada em 1 caso para cada 20 milhões pessoas.

Relato de caso: apresentamos um caso de glucagonoma associado a ENM em um paciente de sexo masculino, 56 anos de idade, com quadro de lesões cutâneas, principalmente em membros inferiores e região inguinal, hiperglicemia e perda ponderal. Biópsias das lesões cutâneas foram realizadas e exames de imagem do abdome evidenciaram uma massa de $10 \times 9 \mathrm{~cm}$ em região pancreática. O paciente foi submetido à pancreatectomia corpocaudal e esplenectomia total com autoimplante do baço em omento maior. O laudo histopatológico foi de tumor de células alfa pancreáticas. Imuno-histoquímica evidenciou expressão de glucagon e cromogranina A na maioria das células tumorais, compatível com diagnóstico de glucagonoma. $\mathrm{O}$ paciente apresentou seguimento de 3 anos em ambulatório sem intercorrências clínicas.

Conclusão: o ENM é importante para o reconhecimento clínico do glucagonoma, sendo seu diagnóstico precoce fundamental para uma terapia curativa de sucesso.

Palavras-chave: eritema migratório necrolítico, glucagonoma, neoplasias pancreáticas, tumores neuroendócrinos.

\section{References}

1. Kovács RK, Korom I, Dobozy A, Farkas G, Ormos J, Kemény L. Necrolytic migratory erythema. J Cutan Pathol. 2006;33(3):242-5.

2. Wermers RA, Fatourechi V, Wynne AG, Kvols LK, Lloyd RV. The glucagonoma syndrome. Clinical and pathologic features in 21 patients. Medicine. 1996;75(2):53-63.

3. Pujol RM, Wang CY, el-Azhary RA, Su WP, Gibson LE, Schroeter AL. Necrolytic migratory erythema: Clinicopathologic study of 13 cases. Int J Dermatol. 2004;43(1):12-8.

4. Becker SW, Kahn D, Rothman S. Cutaneous manifestations of internal malignant tumors. Arch Dermatol Syphilol. 1942;45:1069-80.

5. Wilkinson DS. Necrolytic migratory erythema with carcinoma of the pancreas. Trans St John's Hosp Dermatol Soc. 1973;59(2):244-50.

6. McGavran MH, Unger RH, Recant L. A glucagon-secreting alpha-cell carcinoma of the pancreas. N Engl J Med. 1966;274(25):1408-13.

7. Yao JC, Eisner MP, Leary C, Dagohoy C, Phan A, Rashid A, et al. Populationbased study of islet cell carcinoma. Ann Surg Oncol. 2007;14(12):3492-500.

8. Lobo I, Carvalho A, Amaral C, Machado S, Carvalho R. Glucagonoma syndrome and necrolytic migratory erythema. Int J Dermatol. 2010; 49(1):24-9

9. Remes-Troche JM, García-de-Acevedo B, Zuniga-Varga J, Avila-Funes A Orozco-Topete R. Necrolytic migratory erythema: A cutaneous clue to glucagonoma syndrome. J Eur Acad Dermatol Venereol. 2004;18(5):591-5.

10. Johnson SM, Smoller BR, Lamps LW, Horn TD. Necrolytic migratory erythema as the only presenting sign of a glucagonoma. J Am Acad Dermatol. 2003;49(2):325-8

11. Shi W, Liao W, Mei X, Xiao Q, Zeng Y, Zhou Q. Necrolytic migratory erythema associated with glucagonoma syndrome. J Clin Oncol. 2010;28(20):e329-31

12. Marliss EB, Aoki TT, Unger RH, Soeldner JS, Cahill GF. Glucagon levels and metabolic effects in fasting man. J Clin Invest. 1970;49(12):2256-70.

13. Zhang M, Xu X, Shen Y, Hu ZH, Wu LM, Zheng SS. Clinical experience in diagnosis and treatment of glucagonoma syndrome. Hepatobiliary Pancreat Dis Int. 2004;3(3):473-5.

14. Echenique-Elizondo M, Valls AT, Orue JLE, Lizarduy IM, Aguirre JI. Glucagonoma and pseudoglucagonoma syndrome. J Pancreas. 2004; 5(1):179-85.

15. Xu Q, Chen WH, Huang QJ. Spiral CT localization of pancreatic functioning islet cell tumors. Hepatobiliary Pancreat Dis Int. 2004;3(4):616-9.

16. Castro PG, Leon AM, Trancon JG, Martínez PA, Alvarez Pérez JA, Fernández Fernández JC, et al. Glucagonoma syndrome: a case report. J Med Case Rep. 2011;5:402.

17. Melen-Mucha G, Lawnicka H, Kierszniewska-Stepien D, Komorowski J, Stepien $\mathrm{H}$. The place of somatostatin analogs in the diagnosis and treatment of the neuoroendocrine glands tumors. Recent Patents Anticancer Drug Discov. 2006;1(2):237-54.

18. King J, Quinn R, Glenn DM, Janssen J, Tong D, Liaw W, et al. Radioembolization with selective internal radiation microspheres for neuroendocrine liver metastases. Cancer. 2008;113(5):921-9.

19. Radny P, Eigentler TK, Soennichsen K, Overkamp D, Raab HR, Viebahn R, et al. Metastatic glucagonoma: treatment with liver transplantation. J Am Acad Dermatol. 2006;54(2):344-7

20. Kindmark H, Sundin A, Granberg D, Dunder K, Skogseid B, Janson ET, et al. Endocrine pancreatic tumors with glucagon hypersecretion: a retrospective study of 23 cases during 20 years. Med Oncol. 2007;24(3):330-7 